\title{
OSSIFICATION OF OSSA SESAMOIDEA DISTALIA IN CATTLE
}

\section{C. ČERVENÝ and V. PÁRAL}

\author{
Department of Anatomy, Histology and Embryology University of Veterinary and Pharmaceutical Sciences, \\ 61242 Brno, Czech Republic
}

Received October 27, 1993

\begin{abstract}
Cervený C. and V. Páral: Ossification of ossa sesamoidea distalia in Cattle. Acta vet. Brno, 63, 1994:89-93.

The appearance of ossificaton centres in cartilaginous primordia of ossa sesamoidea distalia was studied in a group of twenty calves of the Bohemian spotted cattle (14 males and 6 females) from birth to three months of age. All calves were X-rayed four times in identical periods. The radiographs showed that ossification centres of ossa sesamoidea distalia were already easily identifiable at the early stages of ontogeny and their appearance was recorded from 1 to 60 days after birth. The centres of ossa sesamoidea distalia appeared 14 to 30 days earlier on the pelvic limbes than in the thoracic limbs. In the pelvic limbs they were fully developed in calves at one month of age while in thoracic limbs they were present at two months. In calves aged 3 months the ossification centres were equally well developed in both the thoracic and pelvic limbs, with the exception of calves retarded in growth. Ossification of the centres occurred earlier in female than in male animals.
\end{abstract}

\section{Cattle, ossa sesamoidea distalia, ossification, skeletal maturity}

Monitoring the health of young cattle under the conditions of large-scale production poses new problems in veterinary medicine. X-ray examination of skeletons in cattle and its correct evaluation must draw on exact anatomical and radiological knowledge. This basic information can be used not only for a radiographical diagnosis of skeletal diseases but also for an evaluation of skeletal maturity of the animal. From this point of view, we studied the development of ossification and radiographical representantion of proximal sesamoid bones of digits in cattle (Červený 1983, 1987).

In the literature, only general observations on the distal sesamoid bones in cattle are usually presented in descriptions of the overall development of the skeleton. Kü p fer and S chinz (1923) found ossification centres of distal sesamoid bones in a 13-day old calf. Vokken (1950) reported ossification centres of ossa sesamoidea distalia in digits of pelvic and thoracic limbs of 10-day old calves and 30 to 40 -day old calves, respectively. When studying radiopgraphs of Jersey calves up to the age of nine months, Roj a s (1943) did not find any ossification centres of distal sesamoid bones in their digits. Fedrig o (1957) stated that he found no ossification centres of the ossa sesamoidea distalia in radiographs of a neonate calf. Neither did D hingra et al. (1975) find any ossification centres of these tiny bones when studying Haryana calves, one to four weeks old. More accurate information on the time of appearance of ossification centres of distal sesamoid bones in digits of Ayshire calves is provided by Lind say et al. (1969). They set the interval for the first appearance of ossification centres of distal sesamoid bones of pelvic and thoracic limbs at 16 to 35 days after birth. On the basis of this finding, they suggest dividing calves of unknown age into those which are under two weeks old and those which are older. This has an essential importance in assessing the calf's slaughter characteristics during a veterinary examination.

In cattle, ossa sesamoidea distalia develop from ossification centres only after birth and are well depicted in radiographs of digits in calves. We can thus determine the time these ossification centres first appear and study their development. These findings, as well as the data on the appearance and shape differentiation of proximal sesamoid bones in cattle (Červený 1983), can then be used as one of the criteria for assessing the skeletal maturity of calves.

\section{Materials and Methods}

For the X-ray monitoring of development of ossification distal sesamoid bones of thoracic and pelvic limbs, we used a group of twenty calves of the Bohemian spotted cattle from birth to three months of age. Radiographs were taken immediately after birth, at the age of 2 weeks and 1,2 and 3 months. For more data on the sex and weight of the calves studied, see Table 1 .

Radiographs were taken in a cattle barn, using a portable X-ray apparatus Chirax. The calves were calmed by xylasin (Rompun) and the limbs to be X-rayed were fastened to a special portable grid. Radiographs of thoracic limbs were taken in dorso-palmar and lateromedial projections, radiographs of pelvic limbs in lateromedial and mediolateral projections. Numerous radiographs were taken in lateromedial or mediolateral oblique projections.

Radiographs were studied on a viewing panel L-110 with four levels of intensity of homogenously dispersed light and the time when ossification centres of the ossa sesamoidea distalia first appeared were determined. The findings are shown in Table 1. 
Table 1

Results of X-ray investigation in experimental group

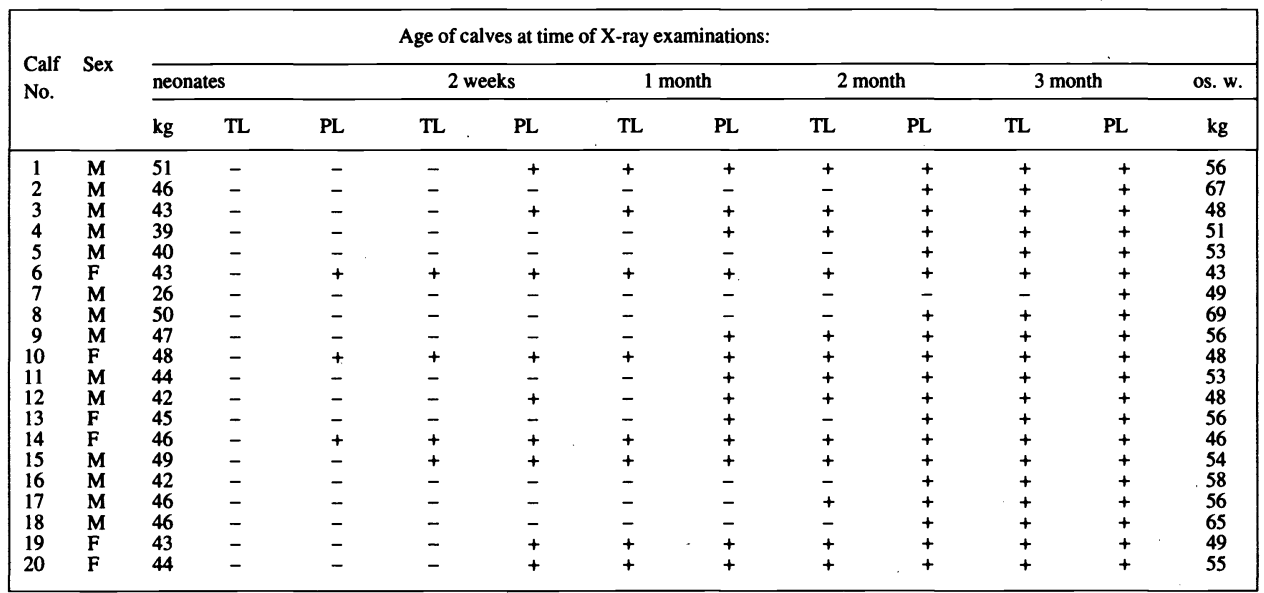

TL thoracic limb

PL pelvic limb

cartilaginous primordium of os sesamoideum distale

$\mathrm{X}$-ray verified ossification centre of os sesamoideum distale

os. $w$. body weight of the calf at the time of the onset of ossification

\section{Results}

The onset of ossification in cartilaginous primordia along the ossa sesamoidea distalia was depicted in radiographs taken in lateromedial and lateromedial oblique projections. In the former, ossification centres of these tiny bones were positioned close together above or next to each other, or they partially or completely overlapped so that their shadows were clearly visible in the radiographs. They were small oval spots, $1-3 \mathrm{~mm}$ in diameter, localized palmarly or plantarly from the shade of the middle phalanx trochlea (Plate I, Fig. 1), In the oblique projection, ossification centres were always localized next to each other and their appurtenance to the third on fourth digit could only be identified from the mutual position of digits in the radiograph, which was determined by the projection used. In the dorsopalmar (dorsoplantar) or palmodorsal (plantadorsal) projections, ossification centres were positioned in the shadow of the distal part of the middle phalanx, which made their identification in this early stage of development difficult (Fig. 2). Ossification centres for ossa sesamoidea distalia appeared in cartilaginous primordia in a regular sequence, in the pelvic limbs first and then in thoracic limbs, within the first two months after birth (Figs 3 and 4). A survey of the onset of ossification of distal sesamoid bones of digits is presented in Table 1 .

In a group a of twenty neonate calves, radiographs failed to demonstrate ossification centres in cartilaginous primordia of ossa sesamoidea distalia in 17 cases $(85 \%)$. In three (15\%) calves (no. 6,10 and 14), tiny ossification centres were found in pelvic limbs only. The calves were heifers of average weight and generally average quality.

Repeated radiographs at the age of two weeks revealed the ossification centres of ossa sesamoidea distalia in eight calves $(40 \%)$, four of which had ossification centres in both pelvic and thoracic limbs. In 12 calves (60\%), radiographs failed to demonstrate any ossification centes of ossa sesamoidea distalia.

In one-month old calves, ossification centres of ossa sesamoidea distalia were found in 14 cases $(70 \%)$. More than half of these calves (8) showed ossification centres in both thoracic and pelvic limbs. In six calves (30\%), no centres were found either in thoracic or pelvic limbs. 
In two-month old calves, ossification centres of ossa sesamoidea distalia were observed in radiographs of 19 calves (95\%), 13 of which had them in both thoracic and pelvis limbs $(65 \%)$ and in six calves ossification centres were found in pelvic limbs only. One calf showed no ossification centres of ossa sesamoidea distalia. Its weight at birth was well below average $(26 \mathrm{~kg}$ ) but otherwise this calf was very lively and full of stamina.

In three-month old calves, ossification centres of ossa sesamoidea distalia were found in all animals. In 19 calves, they were found in both thoracic and pelvic limbs, in one calf (it was again calf No. 7 with less-than-average weight) ossification centres were found in pelvic limbs only.

\section{Discussion}

The development of ossification centres of ossa sesamoidea distalia of the third and fourth digits in cattle can best be identified in radiographs of lateromedial or mediolateral oblique projection. It should be born in mind that, contrary to histological methods, the X-ray method will not be useful in revealing the earliest stages of ossification. It can nevertheless be used with advantage when assessing the skeletal maturity in X-ray examinations of calves under identical conditions. The observations of this study imply that the ossification centres of ossa sesamoidea distalia are easy to identify at the early stages of development by $\mathrm{X}$-ray examination. Their presence was demonstrated in radiographs over the period of 1 to 60 days after birth. They occurred very rarely in neonates but were absent only exceptionally, such as in calf no. 7, in 60-day-old calves. Our results also indicate that a standard time can be set for the appearance of the ossification centres of ossa sesamoidea distalia. In Bohemian spotted calves, as investigated in this work, most animals ( $70 \%)$ showed ossification centres in pelvic limbs at one month of age. Ossification centres in thoracic limbs were not observed in the majority of calves $(65 \%)$ before the age of two months. Ossification occured 14 to 30 days earlier in pelvic than in thoracic limbs. Earlier ossification of distal sesamoid bones in pelvic limbs than in thoracic limbs has also been reported by Vokken (1950) and Linds ay et al. (1969). If we compare the findings on ossa sesamoidea distalia and ossa sesamoidea proximalia in cattle foetuses and neonate calves (Červený 1983), we find the same early ossification of both sesamoid bones in pelvic limbs. This may be also influenced by phylogenetic factors of a greater load on sesamoid bones of pelvic limbs than those of thoracic limbs. This interpretation is based on the data of a comparative study of skeletal ossification of animals (Vokken 1949) and observations by Preuss (1970). Vokken (1949) attributes intraspecies differences in the sequence of the appearance of ossification centres in the skeleton, particularly of secondary centres, to a certain specific functional adaptation of the skeleton during phylogenetic development.

Preuss (1970) believes that sesamoid bones appear as a result of the pressure of muscle tendons against the wall of joint capsules and the earlier appearance of ossification of both proximal and distal sesamoid bones in pelvic limbs can be related to the higher load of pelvic limbs in cattle. Lindsay (1969), on the other hand, found earlier ossification in other parts of the skeleton of thoracic limbs in cattle than in the skeleton of pelvic limbs.

When we compare the data on the appearance of ossification centres of distal sesamoid bones in digits of cattle, we find a broad scope of questions concerning skeletal development. The development of these tiny bones was completely disregarded by some authors in their studies of the skeleton development in cattle (Rojas 1943; Fedrigo 1857; Dhingra et al. 1974). The data by Küpfer and Schinz (1923) can only be accepted as information because the authors used three calves, aged 1, 5 and 13 days, for their studies of postnatal development and, in the 13-day-old calf, the did not state whether the cent- 
res were found in the thoracic or pelvic limbs. The data published by Vokken (1950) on the findings of ossification centres of ossa sesamoidea distalia in the thoracic limb correspond to our findings. On pelvic limbs we only found ossification centres of ossa sesamoidea distalia $40 \%$ of two-week old calves studied, which shows that neither our results or Vokken's data (1950) can be considered as representing a standard. Lindsay et al. (1969) made a single X-ray examination of 12 Ayrshire calves, 2 to 35 days old. The time limits of 16 to 35 days for the appearance of ossification centres of ossa sesamoidea distalia were obtained from their very modest material and there was no opportunity to study more radiographs of calves of the same age. Time standards for the evaluation of skeletal development can only be obtained after repeated examination of a larger number of individuals. On the basis of repeated X-ray examinations of calves we determined a period when ossification centres in cartilaginous primordia of ossa sesamoidea distalia begin to appear in calves of the Bohemian spotted cattle under the conditions of large-scale production.

In view of the limited material processed, it would be difficult to come up with any definite ideas on factors which may influence the time of appearance of the ossification centres studied. It is significant that ossification was long delayed in calf No. 7, whose weight at birth was well below average. On the other hand, however, ossification was also delayed in calves with average or even above-average weight at birth and in the course of postnatal development. Some role may also be played by differences in the genotype of skeleton differentiation, as observed by Garard et al. (1947).

In our small group, a comparison of the time of appearance of the ossification centres in male and female animals showed that this process occurred earlier in females. Five of the six heifers showed earlier ossification than was the standard time set for the whole group and one heifer was within the limit. Earlier skeletal ossification in heifers was also observed by Vokken $(1949,1950)$. He found that, in their first year of life, bulls were lagging behind heifers in skeleton differentiation, although their weight was frequently higher (Table 1). This fact has to be taken into account when the assessment of time aspects of male skeleton development is made.

\section{K osifikaci os sesamoideum distale u skotu}

Na souboru dvaceti telat českého strakatého plemene jsme studovali v časovém období od narození do stáři 3 měsíce vznik osifikačních center $v$ chrupavčitých základech pro ossa sesamoidea distalia. Zastoupeno bylo pohlaví samčí (14 kusủ) a samičí ( 6 kusů). V̌̌echna telata byla opakovaně $4 \times$ rentgenována ve stejných časových intervalech. Po vyhodnocení rentgenogramů vyplynula následující zjištění:

Osifikační centra pro ossa sesamoidea distalia jsme na rentgenogramech dobře identifikovali i v počátečních fázích vývoje. Zachytili jsme jejich vznik v časovém rozmezí 1-60 dnů po narození.

Časový předstih vzniku osifikačních center pro ossa sesamoidea distalia na pánevních koncetinách před vznikem center na končetinách hrudních činí 14-30 dnů.

Časová norma vzniku osifikačních center pro ossa sesamoidea distalia na pánevních končetinách vychází na 1 měsíc stará telata. Norma vzniku těchto osifikačních center na hrudních končetinách vychází na 2 měsíce stará telata. U 3 mèsíce starých telat jsou tato osifikační centra vyvinuta na hrudních i pánevních končetinách pravidelně. Výjimkou mohou být telata zaostalá ve vývoji.

Pozorovali jsme časový předstih v osifikaci studovaných center $u$ samic před samci. Při hodnocení rannosti vývoje kostry podle výskytu osifikačních center pro ossa sesamoidea distalia je třeba vzít v úvahu tuto skutečnost. 


\section{К оссификации оs sesamoideum phalangis distalis крупного рогатого скота}

У двадцати телят чешской пестрой породы исследовали в период с рождения до 3 месяцев возникновение центров оссификации в хрящевой основе дистальных сесамовидных костей. С точки зрения пола были представлены самцы (14 голов) и самки (6 голов). Все телята проходили повторно четыре раза рентгеновскими исследованиями в одинаковых интервалах времени. Оценив рентгенограммы, мы пришли к следующим выводам:

Центры оссифакации дистальных сесамовидных костей на рентгенограммах хорошо выдельялись даже в первоначальных этапах развития. Их возникновение было нами зафиксировано в интервале $1-60$ суток после рождения.

Опережение возникновения центров оссификации дистальных сесамовидных костей тазовых конечностей по отношению к центрам грудных конечностей достигало 14-30 суток.

Норма времени возникновения центров оссификации дистальных сесамовидных костей на тазовых конечностях касается телят в возрасте 1 месяц. Норма возникновения данных центров на грудной конечности касается телят в возрасте 2 месяцев. На грудных и тазовых конечностях телят в возрасте 3 месяца упомянутые центры оссификации развиты симметрично. Исключением могут быть отстающие в развитии телята.

Проводили наблюдения опережения оссификации изучаемых центров у самок и самцев. В ходе оценки протекания развития скелета по наличии центров оссификации дистальных сесамовидных костей необходимо учесть данное обстоятельство.

\section{References}

CERVENÝ, C.: Ossification and development of the ossa sesamoidea phalangis proximalis in cattle (Bos primigenius f. taurus Linné 1758). Acta vet. Brno, 52, 1983: 27-38.

CERVENÝ, C.: Radiograph of ossa sesamoidea phalangis proximalis in cattle in postnatal ontogenesis. Acta vet. Brno, 56, 1987: 231-249.

DHINGRA, L. D.-RAO, H. M. N.-GOYAL, H. O.: Status of loci of ossification and epiphyseal plates in neonatal Haryana cattle (Bos indicus). II. The pelvic limb. Indian vet. J., 52, 1975: 539-543.

FEDRIGO, G.: Studio radiografico sui nuclei ossificazione di feti bovini. Nuova veterinaria, 33, 1957: 45-55.

GARARD, G.-HARRISON, G. A.- WEINER, S.: Genotypic differences in the ossification of 12-day old mice. J. Anat., 117, 1974: 531-539.

KÜPFER. M.-SCHINZ, N. R.: Beitrag zur Kenntniss der Skelettbildung bei domestizierten Säugetieren auf Grund roentgenologischer Untersuchungen. Denkschr. d. Schweiz. Naturf. Ges., 59, 1923: 1-133.

LINDSAY, E. E. F.: Observations on the loci of ossification in the prenatal and neonatal bovine skeleton. I. Appendicular skeleton. Brit. Vet. J., 125, 1969: 101-111.

LINDSAY, F. E. F.-BOYD, J. S.-HOGG, A. D.: A preliminary radiographic study of the time of appearance of the loci of ossification of the distal sesamoids of the young calf. Res. vet. sci., 10, 1969: 589-591.

PREUSS, F.: Zur Sesambeinfrage. IX. International Congress of Anatomists. Abstracts of papers, Leningrad 1970, $199 \mathrm{pp}$.

ROJAS, M.: Estudio radiologico del desarrollo esqueletico del ternero. Rev. de Med. Vet., 12, 1943: 74-100.

VOKKEN, G. G.: Zakonoměrnosti differencirovki kostnogo skeleta mlekopitajušcich. Avtoreferat diss., Lenin$\operatorname{grad} 1949,26 \mathrm{pp}$.

VOKKEN, G. G.: Kostnyj skelet tulovišča i koněčnostej plodov, novoroždennych i molodnjaka krupnogo rogatogo skota. Sb. nauc. tr. Leningrad. inst. usoverš. vet. vrǎej, 5, 1950: 89-103. 
Červený C. and Páral V.: Ossification... pp. 89 - 93

\section{Plate I.}

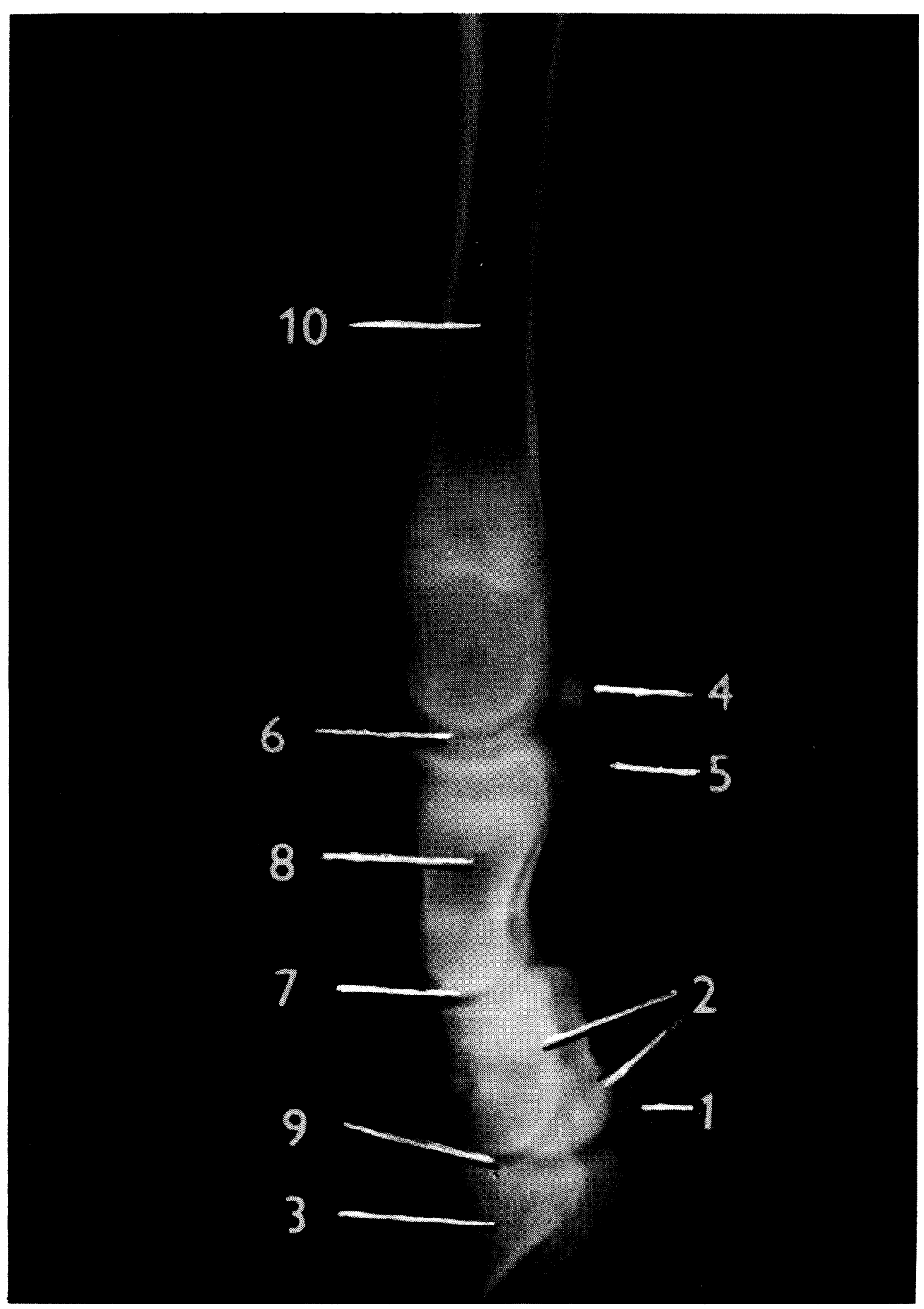

Fig. 1: Onset of ossification in cartilaginous primordia of ossa sasamoidea distalia in the right pelvic limb of a one-month old calf. Mediolateral oblique projection. 1 - ossification centre of os sesamoideum distale, 2 - phalanx media, 3 - phalanx distalis, 4 - ossa sesamoidea proximalia, 5 - ossification centres of phalanges of the primordia of digits 2 and 5, 6 - articulatio metatarsophalangea, 7 - articulatio interphalangea proximalis, 8 - phalanx proximalis, 9 - articulatio interphalangea distalis, 10 - metatarsus III et IV. 


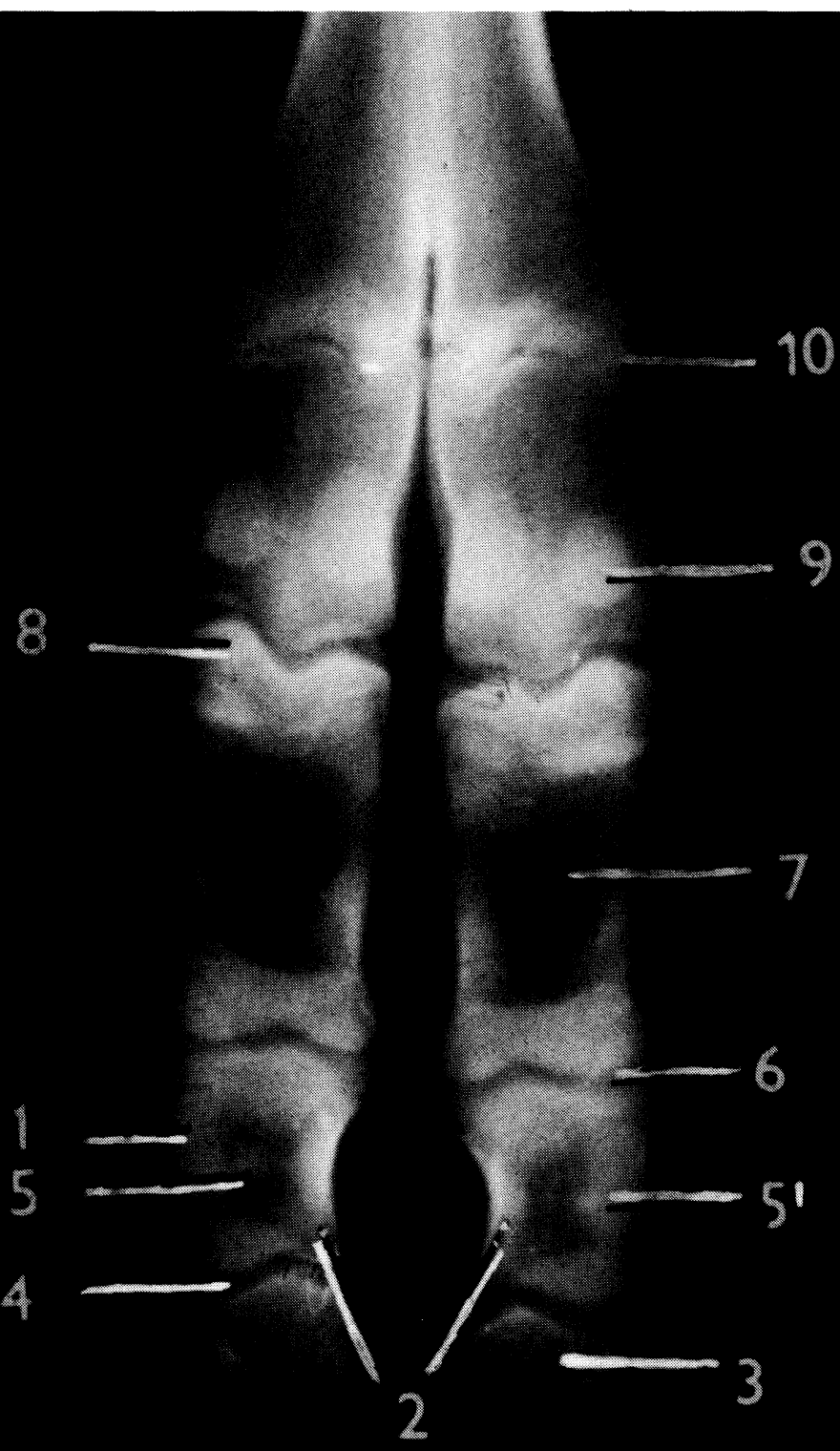

Fig. 2: Digits of the right pelvic limb of a one - month old calf. Plantadorsal projection. 1 - phalanx media, 2 - trochlea phalangis mediae, 3 - phalanx distalis, 4 - articulatio interphalangea distalis, $5,5^{\prime}$ - shadows caused by an ossification centre of the os sesamoideum distale of digit 3 and 4 , respectively, 6 - articulatio interphalangea proximalis, 7 - phalanx proximalis, 8 - articulatio metatarsophalangea, 9 - shadows caused by ossification centres of ossa sesamoidea proximalia, 10 - epiphysodiaphysar growth zone. 


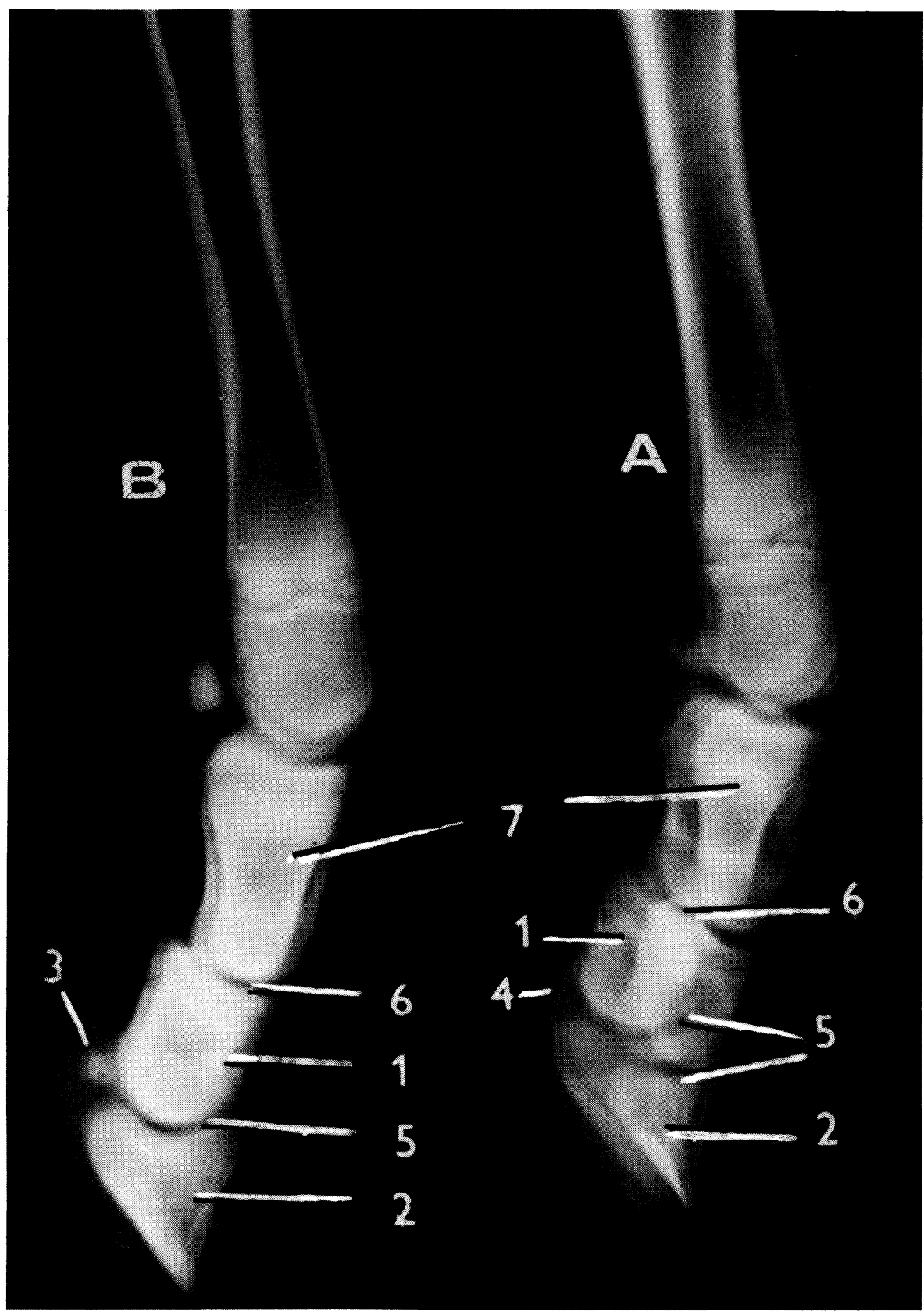

Fig. 3: Ossification centres of ossa sesamoidea distalia in the pelvic limb of a one-month old male calf. No ossification centres have appeared in the thoracic limb. A - distal end of the left thoracic limb. Lateromedial oblique projection. B - distal end of the right pelvic limb. Mediolateral projection. 1 - phalanx media, 2 - phalanx distalis, 3 -ossification centres of ossa sesamoidea distalia in the pelvic limb, 4 - line pointing to cartilaginous primordia of ossa sesamoidea distalia of the thoracic limb, ossification centres in the thoracic limb did not appear, 5 - articulatio interphalangea distalis, 6 - articulatio interphalangea proximalis, 7 - phalanx proximalis. 


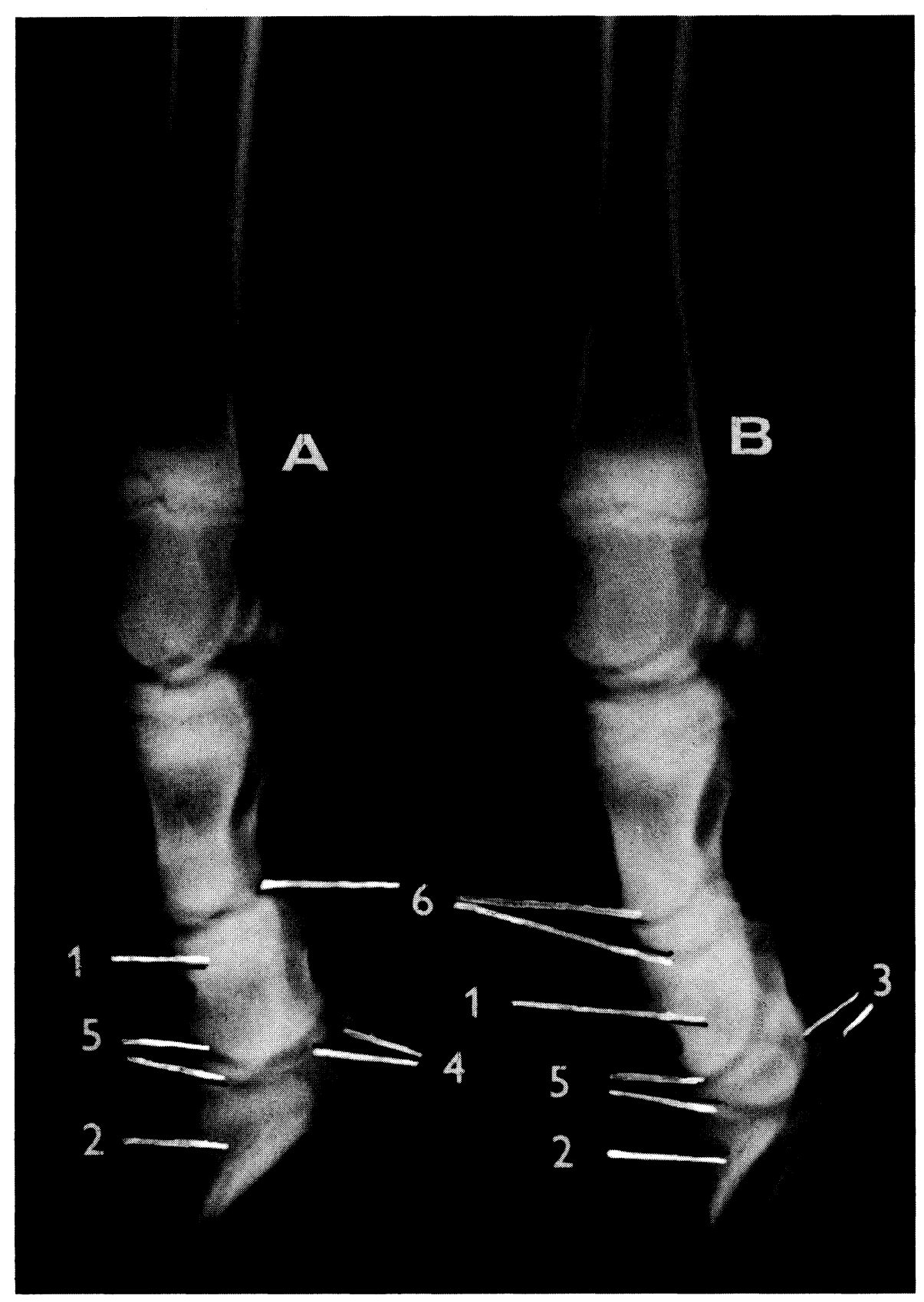

Fig. 4: Ossification centres of ossa sesamoidea distalia in the thoracic and pelvic limbs of a onemonth old female calf. Ossification further advanced. A - distal end of the left thoracic limb. Lateromedial oblique projection. B - distal end of the right pelvic limb. Mediolateral oblique projection. 1 - phalanx media, 2 - phalanx distalis, 3 - ossification centres of ossa sesamoidea distalia in the pelvic limb, 4 - ossification centres of ossa sesamoidea distalia in the thoracic limb, 5 - articulatio interphalangea distalis, 6 - articulatio interphalangea proximalis. 